\title{
BILATERAL INVESTMENT TREATIES: THE CHINESE APPROACH AND PRACTICE
}

\section{Kong Qingjiang*}

1. Introduction

2. An overview of chinese attitudes towards foreign direct investment from the perspective of political economics

2.1. Before 1979

2.2. After 1979

2.3. The tone of the new attitudes towards foreign investment

2.4. The still-evolving attitudes towards foreign investment

3. Overview of the Chinese bilateral investment treaties

4. Features of the Chinese bits

4.1. Preamble

4.2. Scope of Application

4.3. Admission of investment

4.4. Treatment of investment

4.5. Expropriation

4.6. Transfer of funds

4.7. Civil strife

4.8. Dispute settlement

5. Implementation of the chinese bits

5.1. Mechanism for monitoring the implementation of BITs

5.2. The impact of China's accession to the WTO on the implementation of BITs

5.3. Municipal legal environment and the implementation of BITs

6. Conclusion

\footnotetext{
* Hangzhou Institute of Commerce, China. The author wishes to thank the Max Planck Institute for Comparative Public Law and International Law at Heidelberg for a fellowship and the Zhejiang Province Department of Education for a grant.
}

Asian Yearbook of International Law, Volume 8 (B.S. Chimni et al., eds.)

C 2003 Koninklijke Brill NV. Printed in The Netherlands, pp. 105-136. 


\section{INTRODUCTION}

Recent years have witnessed a substantial increase in the influx of foreign direct investment (FDI) into the People's Republic of China (China). According to the UNCTAD World Investment Reports, China has since 1992 been the second largest recipient of FDI among all the economies in the world. This is partly attributable to the attraction of its market size. However, it should be pointed out that despite China's prominence in the eyes of critical Western observers as an outsider in terms of international society, it should be pointed out that China's FDI-friendly laws and regulations, together with its bilateral investment treaties (hereinafter referred to as BITs), ${ }^{1}$ have had a substantial and positive bearing on the influx of FDI.

This paper purports to examine Chinese BIT practice and experience. Needless to say, the Chinese attitude towards FDI determines the features of Chinese BITs. Part 1 will deal with this issue. Part 2 will present a general survey of Chinese BITs. The emphasis will be put on Parts 3 and 4, dealing respectively with the features and the implementation of Chinese BITs.

\section{AN OVERVIEW OF CHINESE ATTITUDES TOWARDS FOREIGN DIRECT INVESTMENT FROM THE PERSPECTIVE OF POLITICAL ECONOMICS}

The fifty-year history of the People's Republic of China can be roughly divided into two stages coinciding with the changes in China's foreign policy: from 1949 to 1979 and then from 1979 up to the present. ${ }^{2}$ The first period saw China's self-imposed economic isolation from the outside world and a hostile attitude towards foreign investment. Since 1979, however, China has adhered to an open-door policy aiming at improving its national power and, accordingly, from that time on began a process of attracting foreign investment. This second period was temporarily interrupted by the consequences of the 1989 Tiananmen incident. $^{3}$

\footnotetext{
1 The text of the BITs hereinafter cited may be found in the annual publication Zhonghua Renmin Gongheguo Tiaoyueji [Collection of treaties of the People's Republic of China], (Shijie Zhishi Chubanshe [World Knowledge Press], Beijing, 1982-1998). Although almost every BIT between China and other countries normally has an authentic English version, some provisions quoted in this paper are based on the author's own translation of the Chinese version. In the event of inconsistency between the authentic English version and the author's translation, the authentic version, of course, applies.

2 The Third Plenary Session of the Central Committee of the Eleventh Communist Party of China in 1978 was a watershed.

${ }^{3}$ Soon after the Tiananmen incident, all the major business partners of China, particularly the United States and the European Community (as it then was), imposed sanctions on China. Some sanctions have not yet been fully lifted, up to the time of writing.
} 


\subsection{Before 1979}

The first period of the history of the PRC saw a rejection of private property in accordance with orthodox Marxism and because of strong resentments on the part of China, relating to the State's bitter experience of colonial oppression and foreign intervention. The concept of private property that has been at the core of the law, including the international law on investment, in Western countries ${ }^{4}$ became an obsolete entity in the socialist context; the definition and protection of private property was not a task of paramount importance for the Chinese Constitution. As a matter of fact, the then Chinese Constitutions ${ }^{5}$ did not clearly recognize the legitimacy of private ownership of means of production . $^{6}$

4 According to PETERSMANN's excellent study on property in the constitutional context, the notion is based on the idea of basic human rights. Both the United States and Europe deal with this issue either in their constitution or in conventions concerning constitutional human rights. See E.-U.PETERSMANN, Constitutional Functions and Constitutional Problems of International Economic Law (1991).

5 There have been four consecutive Constitutions since the founding of the People's Republic of China, i.e. those of 1954, 1975, 1978, and 1982. Each of these constitutions was drafted as an original and was not the amended version of an earlier one. The 1982 Constitution has been amended three times, in 1988, 1993, and 1999.

6 According to socialist dogma, ownership is divided into those of production means and of consumption goods. Private ownership is confined to consumption goods, such as income, savings, house, etc. The 1954 Constitution, the first in the history of the People's Republic of China, did lay down a provision for the protection of "the right of capitalists to own means of production and other capital according to law". At the same time, however, the first Constitution clearly called for control of the negative aspects of capitalist industries and for the gradual transformation of capitalist ownership to a socialist one (see Art.10 of the 1954 Constitution). Even this limited recognition of private ownership turned out to be short-lived as capitalism was eliminated by the end of 1956. From then until 1979 non-public ownership in relation to "production means" did not exist and was not formally recognized by the Chinese Constitutions until 1982, even though foreign-funded enterprises and other businesses came into existence from 1979 on. The 1982 Constitution, while re-affirming the public sector as the foundation of the socialist economic system, vaguely mentioned "individual economy [ $g$ eti jingji] of working people in urban or rural areas" (Art.11 of the 1982 Constitution reads: "Subject to the law, the individual economy of working people in urban and rural areas supplements socialist public ownership. The state protects the lawful rights and interests of the individual economy."), which literally means self-employed individual ownership. It was not until 1988 that the amendment to the 1982 Constitution introduced provisions on the private sector [siying jingji], thus providing, to some degree, a constitutional guarantee of private property. The 1988 amendment in this regard states: "The state permits private economy to exist and develop within the boundary of the law. Private economy is a supplement to the socialist public sector. The State protects the lawful rights and interests of the private sector. The state guides, assists and supervises the private sector by administrative control." It is apparent that the framers of the constitutional amendment did not contemplate the private sector to be on the same footing as the public sector in that the 1988 Amendment identified the private sector as a supplement to the public one. Moreover, the Chinese Constitution and its amendments fail to recognize the right to property as a means of production (Art.13 of the Constitution, before the 1999 amendment, referred to private property as opposed to public property: "The State protects the lawful income, 
Strong resentment of China's bitter experience of imperialist oppression and foreign intervention also introduced a completely new dimension into the notions of international law. ${ }^{7}$ The late HUAN XIANG, senior diplomat and one-time Chairman of the Chinese Society of International Law, observed of "traditional international law":

\begin{abstract}
"Principles and rules of international law since Hugo Grotius's time, (in general) reflected the interests and demands of the bourgeoisie, the colonialists and in particular the imperialists. The big and strong powers have long been bullying the small and weak nations, sometimes even resorting to armed aggression. International law has often been used by the imperialists and hegemonists as a means to carry out aggression, oppression and exploitation and to further their reactionary foreign policies. Apologies for aggression and oppression can often be found in the writings on international law."8
\end{abstract}

Consequently, in relation to foreign investment the inviolability of private property together with the requirement of state responsibility for injury to aliens was publicly repudiated. The early 1950 s witnessed the confiscation of almost all of capitalist industry by the Chinese government through "socialist transformation". Compensation was made in the form of a fixed rate of interest, falling significantly below the traditional "prompt, adequate and effective" standard. Some foreign concessions were expropriated under the auspices of rescinding foreign privileges that were perceived to be the result of plunder under unequal treaties. ${ }^{9}$

It is noteworthy that the foregoing measures taken by China were paralleled by the concerted action of the newly independent countries to assert

saving, house and other lawful property ownership rights."). The position of the private sector was strengthened by the 1999 constitutional amendment. The newly amended Constitution declares that "the individual economy, the private sector and other non-public sectors are important components of socialist market economy". This provision can be arguably interpreted as a recognition of the legitimacy of private ownership of means of production.

${ }^{7}$ For a comment on the Chinese attitude towards international law from the Chinese point of view, see WANG TIEYA, "International law in China: historical and contemporary perspectives", 221 Recueil des cours (1990-II) 263-352. For a detailed discussion of China's attitudes towards international law in this period, see J.A.COHEN and H.CHIU, People's China and international law (Princeton, 1974); also, SHAO-CHUN LENG (Ed.), Law in Chinese foreign policy: Communist China and selected problems of international law (Dobbs Ferry, 1972).

${ }^{8}$ HUAN XIANG, "Strive to build up New China's science of international law", in Selected Articles from Chinese Yearbook of International Law (Beijing, 1983) 3.

9 Art.55 of the Common Programs of the Chinese People's Political Consultative Conference, which acted as the de facto constitution before the first Constitution was promulgated in 1954, provided that:

"[t]he Central People's Government of the People's Republic of China must study the treaties and agreements between the Kuomintang Government with foreign governments and, depending on their contents, recognise, annul, revise or re-conclude them." 
permanent sovereignty of states over the national wealth and resources and to safeguard their economic independence. In the post-war era, the developing countries constituted a thrusting force and their attitude towards investment and expropriation issues gained prominence in the international fora. As a result, the traditional principles of international law such as state responsibility for injuries to aliens and pacta sunt servanda were undermined; a new version of international law with respect to foreign investment, represented by the doctrine of the "permanent sovereignty of states over natural resources", began to take shape. The United Nations General Assembly resolutions on the subject are illustrative in this regard. ${ }^{10}$ China, sharing with these newly independent nations or developing countries the humiliation caused by colonialism, naturally sided with them in calling for the emergence of a "contemporary international law". China put forward the Five Principles of Peaceful Co-existence as "principles for contemporary international relations". ${ }^{11}$ The Five Principles consist of mutual respect for each other's sovereignty and territorial integrity, mutual non-aggression, non-interference in each other's internal affairs, equality and mutual benefit, and peaceful coexistence. They seem to be no more than a repetition of the principles embodied in the United Nations Charter, ${ }^{12}$ while allowing for an expansive and flexible explanation. The unremitting Chinese support for the new doctrines was partly driven by the ambition of the then Chinese leadership to act as spokesman for the developing world.

In conclusion the Chinese attitude towards FDI in the period before 1979 can be summarized as follows:

(1) States have the sovereign right to control the entry of FDI and to regulate the activities of foreign investors in their territories;

(2) The right to nationalise foreign property is an inherent attribute of national territorial sovereignty, and the exercise of this fundamental right is not subject to any pre-conditions such as "public purpose, due process and compensation", and

(3) State contracts or concessions are to be observed, subject to the sovereign power of host countries to mandate re-negotiation, revision or even unilateral modification on the basis of changed circumstances or public interests.

It is understandable for a country in a period of self-imposed isolation to maintain an almost hostile attitude toward FDI. As there was practically no inward FDI flow due to that policy of self-imposed isolation, the Chinese

\footnotetext{
${ }^{10}$ For instance, UNGA Res.1803 (XVII) and 2158 (XXI) on Permanent Sovereignty over National Resources, 3201 (S-VI) on the Declaration on the Establishment of a New International Economic Order, and 3281 (XXIX).

1 The "Five Principles" first appeared in a Sino-Burmese agreement in 1954 and were later incorporated in a Sino-Indian agreement of 1956. Since then China has never spared its efforts to advocate the principles. The reference to the principles can be seen in almost every bilateral diplomatic communiqué to which China is a party.
}

12 Article 2 of the Charter of the United Nations. 
attitude towards FDI was not consolidated into the form of a systematically elaborated investment policy.

\subsection{After 1979}

Changes in policy (particularly, in foreign policy) can lead to a change in attitude towards the international law on foreign investment. When China shifted overnight from its self-imposed isolation policy to an open-door policy, its attitude toward FDI also underwent a dramatic change. The process of integrating the Chinese economy into the world economy warranted a hospitable attitude towards FDI. In fact, never in history was the Central Kingdom more eager to attract FDI to boost its economic development. As a result a great many laws and regulations on the subject were promulgated. China also began to conclude BITs with other nations. It is obvious that utilitarianism or even mercantilism has been the driving force behind the investment legislation.

It should be noted that a new version of Marxism also had an impact on the attitude towards foreign investment. On the one hand, Marxists see FDI as the inescapable result of mass social production and thus as a necessary step in the transition from feudalism to capitalism and ultimately to socialism; on the other hand, it focuses on the potentially detrimental effects of FDI on developing states. ${ }^{13}$ Consequently, China's attitude towards FDI in this period was rooted in mixed feelings of attraction and aversion to FDI, or, in Chinese terms, the tone was encouraging as well as restrictive, with the emphasis on encouragement. ${ }^{14}$ Seen in the light of history, the new Chinese attitude, despite its utilitarian nature, is positive.

\subsection{The tone of the new attitude towards foreign investment}

The new Chinese attitudes towards FDI can be characterized by the so-called "three guiding principles" of international economic co-operation and exchange, i.e. the principles of sovereignty, equality and mutual benefit, and reference to international practice. ${ }^{15}$ The three principles appeared, to a certain extent, to be a copy of the Five Principles of Peaceful Co-existence referred to earlier.

\footnotetext{
${ }^{13}$ See, KENNETH J.VANDEVELDE, "The political economy of a bilateral investment treaty", 92 AJIL (1998) 623.

${ }_{14}$ JINSONG YU, Guoji Touzi Fa [International investment law] (Falü Chubanshe [Law Press], Beijing, 1994) 149.

15 See MeZzHENG YAO, "Legal protection of international investment", in Selected Articles from Chinese Yearbook of International Law (Beijing, 1983) 169-186.
} 
The principle of sovereignty is the key concept of the new Chinese attitude. As put by a Chinese publicist, the other principles flow from the notion of sovereignty. ${ }^{16}$ Although the notion of sovereignty is restricted in the international practice of Western countries and in the Western writings on international law, China still holds a preference for the absolute perception of the notion. ${ }^{17}$ The abrupt decision to utilize FDI, the screening of FDI to serve developmental purposes and even the change in attitude towards expropriation could be explained through the principle of sovereignty.

Equality logically derives from the principle of sovereignty. The principle of equality means, in relation to FDI, equality between the capital-exporting and the capital-importing countries, on the one hand, and between nationals and corporations of different countries on the other. However, the core of equality and benefit lies in mutual benefit; linking equality with mutual benefit results in combining juridical and economic equality, making equality substantive rather than merely formal. In essence, the principle of equality and mutual benefit requires that a balance of the rights and obligations of the parties concerned be maintained.

The principle of reference to international practice is new. International practice means, first of all, widely accepted and workable practice with respect to the business activities of companies and the economic administration of the government. Sometimes it is also referred to as the generally recognised principles and rules governing inter-state relations. It was put forward when China had just emerged from its long period of alienation from international business activities. The principle of reference to international practice implies that China is willing to comply with that recognised international practice as a substitute for international law.

\subsection{The still-evolving attitude towards foreign investment}

The 1989 Tianenman incident temporarily interrupted the process of China's integration into the international community that had begun in 1979. China once again became isolated, suffering from this isolation after both the incident itself and the successive collapse of the Central and Eastern European communist regimes. Fortunately, the isolation was never complete; a certain degree of engagement, particularly in the field of economic co-operation, was maintained. The elaborate engagement policy on the part of the major powers had its positive impact on both China and the outside world. The positive significance for China was obvious; as for the outside world, since a minimum

\footnotetext{
${ }^{16}$ MING WEI, "Hepin Gongchu Wuxiang Yuanze Zai Xian Dai Guojifa Shang de Yiyi [The implications of the five principles of peaceful coexistence for modern international law], Chinese Yearbook of International Law 1985: 242.

17 See CHEN TIQIANG, Guojia Zhuquan huomian yu Guojifa [Sovereignty, immunity and international law], Chinese Yearbook of International Law 1983: 31-35.
} 
of economic contacts was maintained China kept adhering to the principles it had put forward. Interestingly, through maintaining the attitude developed in the post-open-door era, new trends emerged; their effect was that, on the one hand, a new FDI policy evolved in a more investment-friendly way, i.e. proceeding in the direction of liberalization, while, on the other hand, that policy started shifting to the selective promotion of FDI. Its aim was to convert the Chinese economy to a more sophisticated industrial structure. ${ }^{18}$

\section{OVERVIEW OF THE CHINESE BITS}

BITs serve different purposes: insofar as host countries are concerned, the most important purpose of BITs is to attract foreign investment in the interest of development. It is observed that BITs may contribute to this objective in a variety of ways, especially by helping to establish a favourable investment climate, building confidence and sending a positive signal to prospective investors.

From the outset of its change in attitude towards FDI, the Chinese government appreciated that foreign investors would have increased confidence in investing in a country where the government has concluded a BIT with the government of the investors' country. The year 1982 saw the conclusion of the first Chinese BIT, between China and Sweden, which was a landmark in the history of the subject. Albeit a late-comer in attracting FDI and the conclusion of BITs, China has made remarkable progress in this regard. Up to July 1999 China had concluded 94 BITs. ${ }^{19}$

The Chinese practice started with BITs with developed countries. In fact, of the twenty-two Chinese BITs that were concluded before June 1989 (the time of the Tiananmen incident), fifteen belonged to this category. This was no coincidence. As a matter of fact, the countries were selectively targeted for the purpose and developed countries were prioritized. For example, China has BIT links with all OECD member countries except the United States and

18 UNCTAD doc.TD/B/COM.2/5- TD/B/COM.2/EM.1/3.

19 UNCTAD source, available at: http://www.unctad.org/en/docs/poiteiiad2.en.pdf. 
Canada. ${ }^{20}{ }^{21}$ All these BITs, except those with Portugal, Spain, Greece and Iceland $^{22}$ were concluded before June 1989.

For China the developed world has remained the main source of inward foreign investment. ${ }^{23}$ However, it reiterated that its open-door policy was "all-directional", which meant that it was "opening up not only to the developed western countries, but also to the developing world". Consequently, from the outset China also negotiated BITs with developing countries. In fact, concluding BITs with developing countries has assumed extra political significance in that it highlights China's commitment to South-South cooperation. Particularly in the aftermath of the Tiananmen incident, partly due to the sanctions imposed by almost all the developed countries, China accelerated its pace in concluding BITs with developing countries. In fact Chinese BITs with developing countries (including the former Central and Eastern European socialist countries or countries in transition) since June 1989 has outnumbered those with the developed world.

The Chinese BITs with developed countries share similar features because these countries share a similar level of economic development and more or less similar interests in investment issues. For example, though varying from one to another due to the different respective states of balance of power between China and its respective treaty partner, all the BITs with developed countries show little deviation from European-style BITs on which almost all of them are based. In fact, in all cases the model BIT proposed by these developed countries was the OECD Draft Convention on the Protection of Foreign Property. ${ }^{24}$

${ }^{20}$ The OECD currently has twenty-nine members, of which only few (Czech Republic, Hungary, South Korea, Mexico, Poland, Turkey) are developing or transitional countries. Furthermore, they (except Turkey) have become members only recently (after 1994).

${ }^{21}$ China has entered into investment insurance agreements with the United States and Canada in 1979 and 1984, respectively, in order to guarantee subrogation rights under political risk insurance policies issued by their respective governmental agencies to their investors in China. While not normally dealing with general matters such as non-discrimination, the investment insurance agreements establish rules for the settlement of] investment disputes by arbitration between China and the two countries respectively. Nevertheless, these agreements are inherently inadequate to deal with the wider issues arising from trans-national investment between China and the two countries.

The conclusion of a Sino-US BIT was obstructed by the US standpoint that adequate and effective protection of intellectual property rights is an essential element of an attractive investment climate, and its demand that at the time of signature of a BIT the treaty partner make a commitment to implement all obligations under the] WTO Trade-Related Aspects of Intellectual Property Rights (TRIPS) agreement within a reasonable period of time. China was not prepared to do so.

${ }^{22}$ China concluded BITs with Portugal and Spain in 1992, with Greece in 1992 and with Iceland in 1994.

${ }^{23}$ According to an OECD source, the outward investment by OECD member countries account for 75 percent of the global FDI.

24 The 1967 OECD Resolution that introduced the Draft Convention stated that: "(it) embodies recognised principles relating to the protection of foreign property combined with rules to render 
As far as the BITs with developing countries are concerned, these countries have, in spite of their similar development level, far more varied concerns than do developed countries. Accordingly, the Chinese BITs with the developing world show a corresponding variety. Some BITs with developing countries are duplicates of the model BITs of the developed world, while others are based on the model BIT proposed by the Asian-African Legal Consultative Committee (AALCC). ${ }^{25}$

BITs are reciprocal in nature. So are the Chinese BITs: they apply equally to investments from other countries in China and to Chinese investments in the other country in question. In Chinese practice, however, the purpose of its BITs has mainly been the promotion and protection of foreign investment in China. It is no exaggeration to suggest that reciprocity has to a large extent been a matter of prestige rather than reality. Though China has begun overseas investment it has remained a net recipient of investment inflow. In other words, China primarily still plays the role of host country or capital-importing country in the arena of international investment. Unlike most of the developed countries, China has not yet a model BIT of its own and it has therefore had, to a certain degree, to accept the terms and conditions put forward by its developed partners in their respective model BITs. The fact is that China is basically a capital-importing, or host, country and, therefore, apparently not in a position to impose its own terms and conditions on its partners.

With the increase in its national strength, China is set to invest abroad. Under these circumstances, the Chinese companies that have invested or intend to invest abroad are pressing for liberalisation provisions in the Chinese BITs, offering them a sense of security for their investments. China has, as a matter of fact, begun to facilitate outward investment. Even in relation to developed countries, China is no longer a country that only attracts investment from its partners without itself investing abroad. An extreme case is that of Australia. China's investments in Australia in 1990 exceeded those of Australia in China. ${ }^{26}$ Accordingly, China has sometimes adopted a flexible attitude towards liberalisation during BIT negotiations.

After these general remarks on Chinese BITs we should now pay attention to the specific Chinese attitudes towards FDI as reflected in the different BITs and which differ from one another. As accurately pointed out by a foreign

more effective the application of these principles." The Draft was originally intended to become a worldwide, multilateral instrument but never reached that stage. However, it was recommended to OECD member states as a model for investment protection treaties. For a further discussion of the link between the OECD Draft Convention and a model BIT for developed countries, see RUDOLF DOLZER, Bilateral investment treaties (1995) 1- 3.

${ }^{25}$ The AALCC formulated a model BIT from the perspective of the developing countries as a whole. The AALCC model BIT has three versions, with a slight difference in between. See DOLZER, op.cit. at 5 .

${ }^{26}$ In 1990 Australian investment in China amounted to US\$350 million, whereas Chinese investment in Australia was US\$400 million. 
jurist, however, China's acceptance of the widely recognised model BITs signifies its new emphasis on treaty-based rules specifically designed to govern FDI. It not only shows China's eagerness to attract FDI, but also means that China has abandoned its long-standing attitudes towards issues such as expropriation.

\section{FEATURES OF THE CHINESE BITS}

The structure and even the wording of the Chinese BITs are often similar or almost identical to each other. A typical BIT starts with a preamble. The first article deals with the scope of application by providing definitions. The second article affirms the promotion and protection of investments. The following four articles are concerned with the substantive obligations of the Contracting Parties, including the treatment of investment and the guarantee against non-political risks. The seventh and eighth articles usually provide for procedures for dispute settlement between the investor and the host country and between the Contracting Parties. Finally, the last articles regulate the scope of application with respect to time, i.e. the treaty's entry into force and duration, and its territorial scope. We shall see that the earlier BITs are briefer than the later ones and that the BIT is often supplemented by a later protocol or exchange of notes that is deemed to be an integral part of the BIT.

\subsection{Preamble}

As do Chinese laws, all Chinese BITs contain a preamble. The preamble states the object and purpose of the treaty. Examination of these preambles shows that a relatively standard phraseology has evolved in practice. A typical preamble is as follows:

\footnotetext{
"The Government of the People's Republic of China and the Government of ... (hereinafter referred to as Contracting Party), desiring to intensify economic cooperation between both States, particularly, intending to create favourable conditions for investments by nationals and companies of either Party in the territory of the other Party on the basis of the principles of equality and mutual benefit and non-discrimination, recognising that the encouragement and mutual protection of such investments are conducive to stimulating the business initiative and to increasing the prosperity of both States, have agreed as follows: ... "27
}

Compared with the model BITs, the Chinese BITs have two typical features: first, the principles of equality, mutual benefit and non-discrimination

27 For example, the preamble to the China-New Zealand BIT (1988). 
are incorporated in the preamble of every Chinese BIT; second, all Chinese BITs deliberately avoid any reference to "private" business initiatives. The former reflects the long-standing Chinese attitude towards international law and international relations (international economic relations in particular). The latter reflects the status quo in the Chinese economic structure, i.e. the dominance of public ownership. ${ }^{28}$

\subsection{Scope of application}

In any BIT, the scope of application is largely determined by the definitions of such terms as "investors" and "investment". A cursory look would reveal that none of the Chinese BITS was designed to cover all investment activity whatever its form. Only capital movement is covered, while movement of natural persons is left aside. Some Chinese BITs make only cursory mention of the obligation of the contracting parties to facilitate the entry and sojourn of personnel, with the Sino-Australian BIT constituting an exception by granting investors the right to employ top managerial personnel of their choice, regardless of nationality. ${ }^{29}$

\subsubsection{Investors}

Every Chinese BIT contains a definition of the notion of "investors". It is no surprise that, unlike the customary BITs, some of the earlier Chinese BITs exclude Chinese natural persons from the benefits of the treaty. Only Chinese economic entities are referred to as "investors". Although in some other earlier Chinese BITs natural persons were included as investors, ${ }^{30}$ these provisions were of no practical importance due to the prevailing limitations on the economic activities of natural persons under Chinese municipal law. Chinese BITs concluded after the 1988 amendment to the Constitution of the People's Republic of China did include natural persons in the category of investors without exception. For example, the Sino-Bulgarian BIT provides that the term "investors" means:

“ [ ...] In respect of the People's Republic of China:

a) natural persons who have the nationality of the People's Republic of China;

b) economic entities [...] "31

28 See supra, n.6.

29 See Art.IV of the Sino-Australian BIT (1988).

${ }^{30}$ See, for instance, Art.1(2)(a) of the Sino-Finnish BIT (1984), where "investors" are also deemed to include "physical persons who have nationality of the People's Republic of China".

${ }^{31}$ Article 1(2)(b) of the Sino-Bulgarian BIT (1989). 
The change in this regard is probably attributable to the transition from a socialist centralized economy to a market economy, as a result of which the Constitution of the country was amended to the effect that private ownership of means of production was recognized. ${ }^{32}$

Despite the entitlement of natural persons to protection under the BITs, their determination by reference to their nationality can pose problems as far as Chinese law is concerned. According to the Chinese Nationality Law, dual nationality is not recognised. ${ }^{33}$ In theory, an overseas Chinese person may have to choose between his/her Chinese nationality and that of his/her state of residence. In fact, however, such a person, no matter whether s/he also holds the citizenship of a state that is party to a Chinese BIT, is automatically regarded a Chinese if s/he has not officially relinquish his/her Chinese nationality. ${ }^{34} \mathrm{~S} / \mathrm{He}$ falls under the jurisdiction of China and is excluded from the protection of the BIT as a national of the other contracting party. Given that an estimated 70 per cent of the influx of FDI comes from overseas Chinese, although not necessarily from natural persons but in corporate form, it may be that the non-recognition of double nationality has a potential impact upon the influx of FDI. A possible solution would be the adoption of a permanent resident approach, by which permanent residents of other countries are treated as foreign nationals, irrespective of their simultaneous Chinese nationality. Whereas the approach of non-recognition of double nationality forces an overseas Chinese to give up his/her Chinese nationality if s/he wishes to become a beneficiary of a BIT between China and his/her other state of nationality, the permanent resident approach entitles the overseas Chinese to enjoy the benefits of a BIT without having to relinquish his/her Chinese nationality.

With respect to legal persons and other economic entities, most of the Chinese BITs seem to adopt a standard combining incorporation and domicile in delineating the categories of economic entities that can be considered economic entities of the Contracting Parties. The Sino-Japanese BIT, for example, specifically sets forth:

"Companies constituted under the applicable laws and regulations of one Contracting

Party and having their seat within its territory shall be deemed companies of that

Contracting Party." 35

\footnotetext{
32 See supra, n.6.

33 Art.3 of the Nationality Law of the People's Republic of China.

${ }^{34}$ According to Art. 10 of the Chinese Nationality Law, renunciation of Chinese nationality becomes valid upon approval by the competent Chinese authority. The Law does not make it clear whether implied representation of intention to renounce one's Chinese nationality, e.g. showing a foreign passport to the competent Chinese authorities, has the same effect.

${ }^{35}$ Art.1(4) of the Sino-Japanese BIT (1988).
} 
Given that the domicile of a company means the principal place of business under Chinese law, ${ }^{36}$ the standard in fact excludes companies incorporated in China but having their principal place of business in other countries from the application of the BIT concerned.

Some Chinese BITs merely adopt the standard of incorporation. The China-New Zealand BIT, for example, states:

\begin{abstract}
“The term 'companies' means (a) in respect of the People's Republic of China, any companies, economic entities and other legal persons incorporated or constituted in accordance with the laws and regulations in its territory; (b) in respect of New Zealand, any companies, partnership, firms, association and organisations incorporated, constituted or registered in New Zealand, irrespective of their qualification for legal persons or not." 37
\end{abstract}

Other Chinese BITs adopt the standard of control, meaning that companies incorporated or domiciled in a third country but controlled by nationals of either Contracting Party are treated as companies of the Contracting Party concerned. The Sino-Swedish BIT belongs to this category, but the standard applies only in respect of Sweden; this means that companies domiciled in Sweden or, albeit domiciled in a third country but controlled by a Swedish citizen or enterprise, are treated as Swedish investors. ${ }^{38}$ Other Chinese BITs treat companies incorporated in either Contracting Party or controlled by nationals of either Contracting Party as companies of that Contracting Party, thus further broadening the scope of application. A typical example is the Sino-Kuwaiti BIT. ${ }^{39}$ The Sino-Malaysian BIT is another example. However, under the latter BIT, companies controlled by nationals of either Contracting Party but incorporated in a third country are not deemed companies of the Contracting Party unless the third country refrains from extending protection to the companies concerned. ${ }^{40}$

The Chinese BITs use two different approaches in defining "investors". One approach is that each Contracting Party applies its own definition; the other is that a common definition is laid down in the BIT, which applies to "investors" from either Contracting Party. The reason for the former method is that China has its own, somewhat more demanding, regulations regarding the incorporation and business activities of companies and other economic entities. For example, under Chinese law not all companies or entities, let

\footnotetext{
36 Art.39 of the General Principles of Civil Law.

37 Art.1(4) of the Sino-New Zealand BIT.

38 Art.1(2) of the Sino-Swedish BIT.

39 Art.1(4) of the Sino-Kuwaiti BIT (1985).

40 Art.1(10) of the Sino-Malaysian BIT (1988).
} 
alone individuals, have the right to conduct business with foreign companies. ${ }^{41}$ It may therefore be advisable to leave the definition of companies and other entities to the laws of their respective own countries. Some Chinese BITs even incorporate the relevant Chinese company regulations to the effect that the status of investors is reserved to those Chinese state-owned economic organisations that have acquired the right to participate in foreign economic transactions. The Sino-German BIT, for example, defines "investors" as, inter alia:

“... In respect of the People's Republic of China, companies, firms or other economic organisations which are recognised by the Chinese Government, registered and entitled to co-operate with foreign countries on economic matters. ...",42

However, as a result of the intensifying rate of reforms, more state-owned enterprises will be de facto privatised and economic organisations will be deregulated. The exclusion of Chinese private business from foreign economic transactions will, as a consequence, likely cease to have real effect.

Finally, it is worth noting that, in respect of China, Chinese-foreign equity and contractual joint ventures and wholly foreign-funded enterprises which are established in Chinese territory and which invest in the other Contracting Party to the Chinese BIT, are regarded as Chinese entities. ${ }^{43}$ Yet a foreignfunded enterprise that is established in China is treated in practice as a foreign investor in the event that it invests in China.

\subsubsection{Investment}

In the Chinese BITs "investment" is without exception defined as meaning "every kind of asset". To this end a broad, non-exhaustive list of assets is provided. A typical example is that of an elaborately formulated definition of investment, illustrated by a list of five groups of specific rights which include traditional property rights, rights in companies, monetary claims and titles to performance, intellectual property rights as well as concessions and

\footnotetext{
${ }^{41}$ Under the current Chinese law, only entities that have been granted the right to deal in transactions with foreigners or foreign business (duiwai jingying quan) can do so. Individuals could not be a party to a joint venture contract nor other economic contract with foreign elements according to the Chinese-Foreign Joint Venture Law, and the Law of Foreign Economic Contract. For instance, Art. 2 of the Law of Foreign Economic Contracts (shewai jingji hetong fa) provides: "The scope of application of this Law is contracts between the enterprises or other economic organisations of the People's Republic of China and foreign enterprises and other economic organisation or individuals...." In fact individuals were not even recognised by the Law of Economic Contracts (jiji hetong $\mathrm{fa}$ ) before 1993 (when a new amendment allowed natural persons, i.e. "individuals" to become a party to contracts covered by the law) as legitimate partner to a municipal economic contract (as opposed to foreign economic contract).

42 Art.1(3) of the Sino-German BIT (1983).

43 Art.41 para.2 of the General Principles of Civil Law.
} 
similar rights. The Sino-Singaporean BIT, for example, contains the following provision:

“ [...] [T]he term 'investments' shall mean every kind of assets as permitted by each Contracting Party in accordance with laws and regulations and shall include, in particular, but not exclusively:

(a) movable and immovable property and any other property rights such as mortgages, liens and pledges;

(b) shares, stock, debentures of companies or interests in the property of such companies;

(c) claims to money or to any performance under contract having a financial value;

(d) intellectual property rights and good-will;

business concessions conferred by law or under contract, if permitted by law, including concessions to search for, cultivate, extract, or exploit natural resources $[\ldots]^{, 44}$

While "investment" is thus defined as widely as possible, some notions in the definition are new to China. ${ }^{45}$ Goodwill, for example, has no parallel in Chinese legal notions, and its protection poses a problem in China.

The definition of investment gives rise to another issue. Some Chinese BITs, particularly those with the developing countries, confine the benefits of the treaty to investment that is "accepted" or "permitted" by the host contracting party. For example, the Sino-Thai BIT set out a provision to that effect. ${ }^{46}$ The Sino-Malaysian BIT has, in its definition clause, a provision to the same effect. ${ }^{47}$ Obviously, the provision relates to the Chinese position that foreign investments do not have unconditional entry. Other Chinese BITs adopt more liberal wording, stating that they apply to investments effected "in accordance with the laws and regulations" of the host countries. In effect, the laws and regulations of the host country, rather than the BIT itself, determine whether a particular foreign investment may be made. This implies that investments incompatible with these laws and regulations are thus not protected by the BIT. Noticeably, the provision may be acting in a discriminatory manner by distinguishing between two categories of foreign investment originating from the same contracting state: one that is protected by the treaty because it is approved by the receiving state and another which is not so protected because it lacks such approval.

With respect to the scope of application, a typical BIT covers not only the investments made after its conclusion, but also those made before that

\footnotetext{
44 Art.1(3) of the Sino-Singaporean BIT (1985).

${ }^{45}$ For example, Art.5 para.1 of the Chinese-Foreign Equity Joint Venture Law, which lists the assets that may be contributed to the registered capital of the proposed equity joint venture, provides: "Each party to a joint venture make its investment in cash, in kind or in industrial property rights, etc." ${ }^{46}$ Art.2(1) of the Sino-Thai BIT (1985).

47 Art.1 of the Sino-Malaysian BIT.
} 
time. Most Chinese BITs follow the usual pattern in this regard, despite the fact that the purpose of the BITs is, for China, to provide an incentive for future foreign investment. Against the historical backdrop that the Chinese government expropriated large portions of existing foreign property soon after the founding of the People's Republic of China, this provision would appear more significant. However, a few Chinese BITs prescribe that they shall apply to investments made after a certain date previous to their conclusion. ${ }^{48}$ Since some of the existing investment is not within the province of these BITs, the proviso in fact undermines the purpose of the BITs to protect investment.

The Sino-UK BIT is different from all other Chinese BITs. Article 1 provides that the term "investment" includes investments existing at the date of entry into force of the agreement, but provides in an Exchange of Notes that the term shall not apply to certain investments - those in respect of which investors have at the date of entry into force of the agreement "ceased to exercise control or other powers or in respect of which at that date they have ceased to obtain income, payment or such benefit".

With respect to the territorial scope of application, the same Sino-UK BIT is worth special mention. As disclosed by EILEEN DENZA and others, in a comment on the UK experience of BITs, the Chinese government had strongly insisted on political grounds that the BIT should not extend to include Hong Kong before the colony's handover by the UK to the PRC on 1 July 1997. ${ }^{49}$ Therefore, the BIT adopted a compromise in Article 12: this provides that the agreement may be extended to such territories for whose international relations the UK government is responsible, as may be agreed in an Exchange of Notes. Thus, it was made possible for China to exclude the application of the BIT to those Hong Kong companies then investing in China unless China expressly agreed to extend the applicability of the BIT to Hong Kong. Interestingly, after the hand-over of King Kong the investments by Hong Kong companies in the UK are no longer automatically entitled to protection under the BIT unless the UK government expressly agrees so to do.

\subsection{Admission of investment}

Despite the fact that the Chinese BITs impose an obligation on each contracting party to encourage and facilitate investment from the other contracting

\footnotetext{
${ }^{48}$ For instance, Art. 8 of the Sino-Swedish BIT which was concluded in 1982 states: "The agreement applies to investments made after 1 July 1979." Art.7 of the Sino-Soviet BIT also deals with the same issue.

49 E.DENZA et al, "Investment protection treaties: United Kingdom experience", 36 ICLQ (1987) 918.
} 
party, ${ }^{50}$ they all fail to create an obligation to admit foreign investment unconditionally. Usually, a Chinese BIT provides that each contracting party shall admit investment from the other contracting party in accordance with its own law. For example, Article 2(1) of the Sino-Japanese BIT clearly states:

"Each Contracting Party shall, to the extent most possible, promotes investment within its territory by nationals and companies of the other Contracting Party, and accord, in accordance with relevant its laws and regulations, license."

It is interesting to note that the Sino-Danish BIT refers to the administrative practice of the host country as well as its laws. ${ }^{51}$ According to their standard phraseology the Chinese BITs create an obligation on the part of both contracting parties to facilitate the entry of investors from the other contracting party rather than to recognize a right to such entry. In fact, each proposed investment project, irrespective of the form and the amount of investment is, under current Chinese investment law, subject to a screening process by the competent government authorities. ${ }^{52}$ As in other developing countries that maintain screening processes for foreign investment, the screening in China is designed to serve the priorities of the national economy and, probably, political purposes. ${ }^{53}$ The government can use the screening process to secure the precedence of public ownership in the ownership structure of a certain industry that is ideologically regarded as part of the economic base of the communist regime. Since China has traditionally been an administrative power-dominant society and, particularly, a highly centralised economy until its commitment to market economy in the past decade, the screening process, no doubt, is of particular importance for the government to be able to play a role in the functioning of the economy. Behind this approach stands the idea that China will not allow to enter into China investment that it does not want.

\footnotetext{
so See, e.g., Art.2(1) of the Sino-Soviet BIT (1990): "Each contracting party shall encourage investment in its territory by investors of the other contracting party...". The Sino-Singaporean BIT makes the obligation to encourage investment more assertive in its languages: "Each Contracting Party shall, having regard to its plans and policies, encourage and facilitate investments in its territory by the nationals and companies of the other Contracting Party."

51 Art.2 of the Sino-Danish BIT (1985).

52 See Art.3 of the Chinese-Foreign Equity Joint Venture Law, Art.5 of the Chinese-Foreign Contractual Joint Venture Law, Art.6 of the Wholly Foreign-funded Enterprises Law.

${ }^{53}$ A typical example is the exclusion of foreign investment involvement in the press, broadcasting and other media industry, an exclusion viewed as crucial to the rule by the party.
} 


\subsection{Treatment of investment}

The treatment standard is the core part of BITs. The predominant standard of treatment in the Chinese BITs is the "fair and equitable treatment" standard. Almost all the BITs in question have a provision to this effect ${ }^{54}$ although a variety of phrases can be found, such as "adequate protection and security", "most constant protection and security" and "full protection and security" ("d'une pleine protection et d'une entière sécurité"). It is argued that, in relation to arbitrary, discriminatory or abusive treatment that is contrary to customary international law, unfair and inequitable treatment is a much wider concept; it may readily include the impact of administrative measures in, for example, the field of taxation and licensing, such that the right to fair and equitable treatment warrants wider protection than most-favoured-nation treatment and national treatment. ${ }^{55}$ Yet the provision is per se so general as to require clarification. The critical issue here is whether "fair and equitable treatment" is equivalent to the traditional "minimum international standard". The prevailing attitude among Chinese publicists in this regard is against equating "fair and equitable treatment" with "minimum international standard" ${ }^{56}$ The reason behind the unappeasable aversion may be traced back to the humiliation caused by the unequal treaties and the regime of extraterritoriality imposed on China in the colonial period under the guise of the socalled minimum international standard. Therefore, while the general standard of fair and equitable treatment appears likely to secure "full protection and security", it may lead to a different understanding in the Chinese context.

Following the general pattern, the Chinese BITs adhere to the standard of most-favoured-nation treatment. The clause is too familiar to need further comment, except in its elaborated exceptions. In this connection, the Chinese BITs with Sweden, Thailand and the Netherlands are worth attention.

The principle in its general form entitles the beneficiary to the more favourable treatment awarded to a third party both before and after the treaty (with the beneficiary) has entered into force. However, the Sino-Swedish BIT prescribes that the contracting parties have the right to retain more favourable treatment for a third party in accordance with the previous commitments made to that third party. ${ }^{57}$

An interesting provision can be found in the Sino-Dutch Treaty, which reads: "A difference may be made between investors investing in free trade zones or engaging in frontier trade and investors not investing in such zones or engaging in such trade". ${ }^{58}$ This provision is not only an exception to the

\footnotetext{
${ }^{54}$ For example, see Art.3(1) of the Sino-Lithuanian BIT (1993).

55 F.A.MANN, "British treaties for the promotion and protection of investment", 52 BYIL (1981) 243.

${ }^{56}$ For example, see JINSONG YU, op.cit.n.14 at 250-251.

57 Art.2(3) of the Sino-Swedish BIT.

58 Art. 3.5 of the Sino-Netherlands BIT (1985).
} 
most-favoured-nation standard, but constitutes a kind of positive discrimination. It plainly takes into consideration the different treatment that is offered in the Chinese Special Economic Zones (SEZ) and in the frontier trade cities.

It is necessary to distinguish the treatment of the entry or admission of foreign investment from that of the operation of investment in the context of national treatment. ${ }^{59}$ As mentioned before, the Chinese BITs do not grant the right of entry or, in other words, there is no national treatment in respect of investment admission. As to the operation of investment: China has so far also been reluctant to grant national treatment to investors from the other state party to the Chinese BITs. ${ }^{60}$ The need for protection of national industries from competition and for the maintenance of state enterprise monopoly offers some explanation of this policy.

The Sino-UK, Sino-Japanese and Sino-Icelandic BITs offer interesting exceptions to the standard of national treatment. The three BITs contain a rule that, in fact, reduces the significance of the national treatment standard to a merely symbolic one. For example, the Sino-Icelandic BIT states:

\footnotetext{
"Unless otherwise stipulated in the above paragraphs 1 and 2, either contracting party shall, to the extent possible, accord treatment in accordance with the stipulations of its laws and regulations to the investments of nationals or companies of the other contracting party the same as that accorded to its own nationals or companies." 61
}

The balancing of the qualifications "to the extent possible" and "in accordance with the stipulations of its laws and regulations" can lead to no other conclusion but that of being the product of Chinese flexibility. Noteworthy in this regard is the phrase "national treatment" which differs from the widely accepted one "no less favourable", thus excluding the possibility for the foreign investor to enjoy treatment more favourable than that accorded to the Chinese counterparts.

Quite often, the Chinese BITs adopt a comprehensive set of treatment standards, combining fair and equitable treatment, non-discriminatory treatment and most-favoured-nation treatment. The Sino-Australian BIT incorporates the three standards in one article, although in most other Chinese BITs they are scattered among diverse articles. Though these standards overlap in one way or the other, they supplement each other in ensuring a desirable treatment for investors. The fulfilment of the entailing obligations by the Chinese government requires, to some extent, the fulfilment of an implied

\footnotetext{
59 Some Chinese BITs, such as the Sino-Japanese BIT, specifically distinguish treatment of the entry or admission of foreign investment from that of the operation of investment.

${ }^{60}$ According to Art.3 of the Sino-Japanese BIT, national treatment as well as most-favoured-nation treatment is awarded to investors with respect to their operation in the host country while, according to Article 2(2) only most-favoured-nation treatment is awarded with respect to the admission of investment.

${ }^{61}$ Art.3(3) of the Sino-Icelandic BIT (1994).
} 
obligation, viz. the transparency of laws and regulations. If a policy remains "internal", it is by its nature not accessible to every foreign, or even domestic, investor and, consequently, can be regarded neither as non-discriminatory nor as satisfying the obligation of MFN treatment and national treatment. Therefore, some of the Chinese BITs, e.g., the Sino-Turkish BIT, require the contracting parties to guarantee transparency. ${ }^{62}$

Finally, the Chinese BITs as a rule set forth that the most favourable treatment among those stipulated in laws or in contracts between investors and the host government or those stipulated in the BIT concerned shall apply.

\subsection{Expropriation}

Expropriation is the central issue of the international law on investment as well as the most controversial part of the Chinese attitude towards foreign investment. A prevailing, albeit controversial, approach of BITs to this issue may be put in this way:

"Expropriation can occur only in accordance with international law standards, that is, for a public purpose, in a non-discriminatory manner, under due process of law, and accompanied by payment of prompt, adequate, and effective compensation." ${ }^{\text {"63 }}$

Compared with the "international law standard", the Chinese practice in this regard, although still different from that standard, has substantially diverged from its long-standing attitude since the early 1980s. A selfrestrained provision on expropriation in the Wholly Foreign-funded Enterprise Law of 1986 states in its Article 5:

"The State does not nationalise and expropriate wholly foreign-funded enterprises, except under special circumstances; for the social and public good wholly foreignfunded enterprises may be expropriated in accordance with legal procedures and upon corresponding compensation."

The Chinese BITs reflect this new attitude. Without exception all these BITs provide that investments of nationals or companies of a Contracting Party may not be expropriated except for a public purpose and then against reasonable compensation. A typical provision in this regard reads as follows:

"Investments of nationals or companies of either Contracting Party in the territory

of the other Contracting Party shall not be subjected to expropriation or nationalisation

62 Art.2(4) of the Sino-Turkish BIT (1990).

${ }^{63}$ See the US Bilateral Investment Treaty Program, at http://www.state.gov or http://www.ustr.org. 
or any measures equivalent thereto, except for public use, in accordance with appropriate legal procedures and upon payment of compensation." 64

However, since many foreign investments take the form of Chinese-foreign joint ventures that are Chinese legal entities, the protection of equity and other interests in these joint ventures is of great concern. The Chinese-Foreign Equity Joint Venture Law failed to close the legislative loophole when it omitted to set forth a provision with regard to expropriation of foreign equity in Chinese-foreign joint ventures similar to the one in the Law on Wholly Foreign-funded Enterprises. In this connection, some Chinese BITs provide for a specific rule to this end. For example, the text of Article 5 paragraph 2 of the China-UK BIT reads:

"If companies incorporated in any place of the territory of one Contracting Party in which nationals or companies of the other Contracting Party hold shares are expropriated by the previous Contracting Party in accordance with its appropriate laws, the Contracting Party shall guarantee the application of the provision of Paragraph 1 of this Article general provision of expropriation to secure that nationals or companies of the other Contracting Party receive reasonable compensation in connection with the investments concerned."

Clearly countries resort steadily less frequently to massive expropriation for achieving their particular economic purposes and thus increase the prominence of the standard of compensation in individual cases of expropriation. The Chinese BITs are flexible in relation to standards of compensation, deliberately avoiding an explicit reference to prompt, adequate and effective compensation, although the wordings used have an effect similar to a reference to that standard. The Chinese BITs usually mention compensation in general, some provide for "appropriate compensation" and others for "reasonable compensation", but the general phrase is always supplemented by phrases such as "without delay", "effectively realisable" and "freely transferable". With respect to the amount of compensation, the Chinese BITs prescribe that this shall be "the value of the expropriated investment immediately before the measure becomes public knowledge". Some BITs provide for the "equivalent to the true value of the expropriated property at the time of declaration of the expropriation". ${ }^{65}$ It is interesting to note in this context that the earlier Chinese BITs seem deliberately to have avoided any reference to "market value" which may contribute to disagreements between the Chinese government and foreign investors. For example, the Sino-UK BIT refers to the real value instead of the more usual "market value". However, the BITs concluded after 1992, e.g., the Sino-UAE one, adopt the standard of market value. ${ }^{66}$

\footnotetext{
${ }^{64}$ Art.6(1) of the Sino-Indonesian BIT (1994).

${ }_{65}$ See, e.g., Art.4 of the Sino-Icelandic BIT.

${ }^{66}$ Art.6(4) of the Sino-UAE BIT (1993).
} 
As to the modality of payment of compensation, nearly all the Chinese BITs warrant that "payment shall be freely convertible and transferable and without delay". The Sino-Icelandic BIT even provides for a time limit of maximum six months for the payment. ${ }^{67}$

\subsection{Transfer of funds}

The Chinese BITs as a rule stipulate that capital, return and other lawful benefits can be converted into foreign currency and transferred overseas. The Sino-UK BIT provides:

"Each Contracting Party guarantees to nationals or companies of the other Contracting Party the right to transfer freely to the country where they reside their investments and returns and payments made pursuant to a loan agreement in connection with any investment." 68

The Sino-Netherlands BIT provides in detail the different categories of transferable funds as follows: (1) profits, interests, dividends and other current income; (2) funds necessary for the acquisition of raw or auxiliary materials, semi-fabricated or finished products; (3) funds necessary to replace capital assets in order to safeguard the continuity of an investment; (4) additional funds necessary for the development of an investment; (5) earnings of employees of an investor or an enterprises in which the investor has invested; (6) the proceeds of the liquidation of capital; (7) funds in repayment of loans; (8) management fees; $(9)$ royalties. ${ }^{69}$

Freedom of the transfer of funds being generally ensured, such transfer must be accomplished in consonance with the procedures set forth in laws and regulations. Article 8 (2) of the China -Japan BIT specifically states that the transfer shall be without prejudice to foreign exchange control carried out by either Contracting Party in accordance with its laws and regulations. Under the Chinese foreign exchange regulations any transfer of funds must be effectuated from the balance of foreign exchange deposit accounts with a Chinese Bank. The Sino-Thai BIT explicitly states:

“... [I]n relation to the People's Republic of China, the free transfer shall be effected in accordance with the foreign exchange control laws and regulations of the People's Republic of China, from the foreign exchange deposit account of the nationals and companies of the Kingdom of Thailand or of the enterprises in which the nationals

\footnotetext{
${ }^{67}$ Art.4 of the Sino-Icelandic BIT.

68 Art.6(1) of the Sino-UK BIT (1986).

${ }^{69}$ Art.4 of the Sino-Netherlands BIT.
} 
and companies of the Kingdom of Thailand have invested either solely or jointly in the territory of the People's Republic of China."70

Under the Chinese BITs, the Chinese government promises to provide special guarantees where the foreign investors' foreign exchange account balance is not sufficient to make the required transfer. For example, the Sino-UK BIT obliges the Chinese government to permit the transfer of local currency as converted into foreign exchange upon request by the British investor for the following items: (1) the proceeds resulting from full or partial liquidation of the investment; (2) royalties derived from copyrights, industrial property rights, or know-how and good will, (3) payments under a loan agreement in connection with an investment guaranteed by the Bank of China and (4) profits, interest, capital gains, dividends, fees and any other form of return of a British national or company specifically permitted by the competent authority of China to carry out economic activities mainly in the territory of China. ${ }^{71}$

There are exceptions to the general freedom of transfer. For example, the Sino-UK BIT states in its Article 6(2) that freedom of transfer "is subject to the right of each Contracting Party in exceptional balance-of-payments difficulties and for a limited period to exercise equitably and in good faith powers conferred by its laws". The Sino-Thai BIT interestingly provides that in case of transfer difficulties "the nationals and companies of the Thai Kingdom who have invested in the People's Republic of China may apply to the competent authorities of the People's Republic of China, who shall accord their "sympathetic consideration" and render "favourable assistance."72

\subsection{Civil strife}

Civil strife includes war, armed conflict, revolution, national or regional emergency, revolt, or riots in the territory of one Contracting Party that cause disturbance to the operation of investments of the other Contracting Party. In this respect some BITs omit mention altogether, while others pass superficially over the issue, since civil strife does not emanate from any wilful act of the host government which is, consequently, not liable for compensation. However, where the government decides to make compensation for the loss incurred as the result of civil strife, the relevant standard of compensation shall apply. Most Chinese BITs contain a provision such as the following, to be found in the Sino-UK Treaty:

70 Art.1(a) of the Protocol to the Sino-Thai BIT.

71 Art.6.4 of the Sino-UK BIT.

72 Art.2(b) of the Protocol to the Sino-Thai BIT. 


\begin{abstract}
"Nationals or companies of one Contracting Party whose investments in the territory of the other Contracting Party suffer losses owing to war or other armed conflicts, revolution, a state of national emergency, revolt or riot in the territory of the latter Contracting Party shall be accorded by the latter Contracting Party no less favourable treatment than that which the Latter Contracting Party accords to nationals or companies of any third State."73
\end{abstract}

Understandably the Chinese BITs do not prescribe national treatment for such situations since the Chinese entities, most of which are state-owned enterprises, would have to rely on the government for assistance in case of loss due to civil strife.

\title{
4.8. Dispute settlement
}

With respect to disputes, a distinction is generally drawn in BITs between state-state and state-investor disputes. The former are treated as disputes between equals, while the latter are disputes between a sovereign and an alien under the state's territorial jurisdiction. The international means for the settlement of the first mentioned disputes are well established, such as consultation, mediation and conciliation. The state-investor disputes were, for a long time, deemed by some countries, especially in Latin America, to fall exclusively under the jurisdiction of the host countries. ${ }^{74}$ Due to the controversial nature of the international approach the first Chinese BIT (with Sweden) even omitted a provision on the settlement of state-investor disputes. BITs usually grant foreign investors the right to submit these disputes to international arbitration, notwithstanding the requirement of the host country first to exhaust the remedies available in that country's domestic courts.

The Chinese tradition of avoiding litigation has had a substantial effect on the model of dispute settlement in the Chinese BITs. All these treaties attach a certain degree of importance to the role of consultation or "amicable means" in the settlement of disputes, irrespective of whether a state-state or a state-investor dispute is concerned.

With respect to state-state disputes, the Chinese BITs without exception require that disputes be amicably settled "to the extent possible, through diplomatic channels" or "through consultation", or "through negotiation or conciliation". Only after the diplomatic channels or consultations have failed to settle the dispute within a certain period of time may the parties refer the dispute to an ad hoc Arbitration Tribunal. The pursuance of a negotiated

\footnotetext{
73 Art.4(1) of the Sino-UK BIT.

${ }^{74}$ For a Latin-American perspective of settlement of state-investor disputes, see, generally, DoNALD R.SHEA, The Calvo Clause: a problem of Inter-American and international law and diplomacy (Univ. of Minnesota Press, Minneapolis, 1955).
} 
settlement of disputes prior to initiating arbitration proceedings without doubt shows the Chinese lack of affinity for international arbitration.

The more recent Chinese BITs have made consultation an even more prominent mechanism for the settlement of state-state disputes. For example, the Chinese BITs with both Turkey and Vietnam lay down consultation procedures. Article 6 of the China-Turkey BIT reads:

"The Contracting Parties agree to, upon request of the other party, hold consultation promptly with a view to the settlement of any disputes arising from this Agreement and to discuss any matters regarding interpretation and application of this Agreement."

Moreover, consultation between the two contracting parties appears to be designed not only as a mechanism for dispute settlement, but also as a mechanism for the supervision of the implementation of the BIT. This will be discussed in Part 5.

With respect to state-investor disputes, the earlier Chinese BITs differ widely from those concluded later. Firstly, the more recent BITs are more liberal in allowing investors to resort to international arbitration, while the earlier Chinese BITs either omitted altogether any provision regarding the settlement of these disputes, or emphasised local remedies. The first Chinese BIT, the Sino-Swedish BIT, was silent on this point. The BITs with Kuwait, Denmark, the Netherlands, France, Belgium-Luxembourg and Norway all contain procedures for local remedies, which investors are required to exhaust before seeking resort to international arbitration. ${ }^{75}$ The Chinese BITs with France and New Zealand refer to international arbitration as a means specifically for the settlement of state-investor disputes concerning the amount of compensation in event of expropriation. ${ }^{76}$ The provision reflects the assumption that state-investor disputes are more likely to arise in relation to compensation in the event of expropriation than on the question of the international lawfulness of expropriation. In this regard, the Chinese BITs with Kuwait and Australia, BITs with France and New Zealand to the effect that under these BITs disputes other than those concerning the amount of compensation can be referred to international arbitration provided the disputing parties agree to do so, ${ }^{77}$ differ from the Chinese BITs with France and New Zealand.

Secondly, the earlier Chinese BITs distinguish between disputes arising from expropriation and other types of dispute. The China-Finland BIT is an example. It requires all state-investor disputes, except those arising from expropriation, unless agreed otherwise, to be settled through local remedies

\footnotetext{
75 For example, according to Art.8 of the Sino-French BIT the state-investor investment dispute shall first be referred to the Administrative authority or the competent municipal court for a solution. Only where a solution acceptable to both disputing parties fails to be reached, the dispute may be submitted to arbitration procedures.

76 Art.8(3) of the Sino-French BIT, Art.13(3) of the Sino-New Zealand BIT.

77 Art.8(3) of the Sino-Kuwaiti BIT, Art.12(2) (b) of the Sino-Australian BIT.
} 
in accordance with the laws and regulations of the host state. ${ }^{78}$ With respect to state-investor disputes arising from expropriation, it further distinguishes between the issues of lawfulness and compensation. In case of a dispute regarding the lawfulness of the expropriation, the BIT provides that the competent municipal court is the only institution responsible for the settlement of the dispute. As for disputes concerning compensation, either the competent municipal court or an ad hoc Arbitration Tribunal may settle the dispute. ${ }^{79}$

The China-Turkey BIT has special provisions in this regard. ${ }^{80}$ It starts by requiring the disputing parties to solve the dispute through consultation. If the process of consultation fails to end in a settlement, the dispute may be referred, for a non-binding opinion, to a third party to be chosen by agreement between the disputing parties.

Thirdly, if the above two procedures fail to solve the dispute, it shall, except where it has arisen from expropriation or nationalisation, be referred to the competent municipal court. The treaty further provides that disputes arising from expropriation or nationalisation shall be submitted to an ad hoc Arbitration Tribunal or to ICSID (provided both parties have acceded to the Convention on the Settlement of Investment disputes between States and Nationals of other States). The condition of consultation and mediation prior to initiating arbitral or judicial proceedings clearly shows the strong Chinese preference for an informal settlement mechanism.

As to the rules on arbitration, the Chinese BITs are not uniform. Some BITs have opted for the UNCITRAL rules ${ }^{81}$ other BITs have enabled the Arbitration Tribunal to lay down its own rules ${ }^{82}$ and still other BITs refer to the ISCID rules. ${ }^{83}$ The absence of acceptance of the ISCID rules in some of the earlier Chinese BITs reflects the Chinese concern to safeguard its longstanding perception of sovereignty. ${ }^{84}$ However, since China acceded to the 1965 ICSID Convention in 1992, China and its treaty partners have begun to refer to the ICSID rules rather than to the UNCITRAL rules in their negotiations on BITs; China and France, after China joined the ICSID convention, have even called for the adoption of the ISCID rules in an exchange of notes relating to their BIT..

The Chinese BITs usually do not prescribe the applicable law in the event of international arbitration in state-investor disputes. Exceptionally, however,

\footnotetext{
78 Art.3 of the Protocol to the Sino-Finnish BIT.

79 Art.2 of the Protocol to the Sino-Finnish BIT.

80 Art.7 of the Sino-Turkish BIT.

${ }^{81}$ For example, Art.4(3) of the Protocol to the Sino-French BIT.prescribes reference by the Arbitration Tribunal to the UNCTRAL.

${ }^{82}$ For example, Art.9(3) of the Sino-Soviet BIT states that the Arbitration Tribunal formed by the parties in dispute may lay down arbitration rules with reference to the Arbitration Rules of the Arbitration Institute of the Stockholm Chamber of Commerce.

${ }^{83}$ Art.13(6) of the Sino-Singaporean BIT is such a provision.

${ }^{84}$ See CHEN, loc.cit n.17.
} 
some treaties specifically state that the municipal law of the host country as well as international law shall be the applicable law in disputes concerning the amount of compensation in the case of expropriation. ${ }^{85}$ The Sino-Kuwaiti BIT prescribes:

"The Arbitration Tribunal shall reach its decision in accordance with provisions of this Agreement, relevant domestic laws, agreements concluded between the contracting parties and general principles of international law."

Obviously, the inclusion of domestic law reduces the symbolic significance of international arbitration. Moreover, it is worthwhile to note in this context that the Chinese BITs tend to confine international law to rules of general international law recognised by both the Contracting Parties. We find this, inter alia, in Article 12 of the Sino-UK BIT.

\section{IMPLEMENTATION OF THE CHINESE BITs}

\subsection{Mechanism for monitoring the implementation of BITs}

There are very few data on the practice of the implementation of the Chinese BITs and the information available on their application is mostly anecdotal. China usually complies well with its BITs, yet some BITs are, paradoxically, relatively unknown among the foreign investors (in contradistinction to providers of finance and insurance) despite the concern of investors with precisely the issues regulated by the BITs. It is, therefore, encouraging that a special mechanism has been established in some Chinese BITs in order to supervise their implementation. The BITs with Japan, the (former) Soviet Union, Turkey, Bulgaria, Vietnam, Croatia, Tajikistan and Lithuania all provide consultative procedures to that effect. However, the clauses embodying the consultative mechanism vary from very general statements of intent to quite detailed regulation of the specific framework for such consultation. For example, Article 14 of the Sino-Japanese BIT reads:

"Both Contracting Parties shall establish a Joint Committee, consisting of representatives of the Governments of both Contracting Parties, for the purpose of reviewing the implementation of the present Agreement and the matters related to investment between the two countries, holding consultations on the operation and the matters related to the operation of the present Agreement in connection with the development of legal systems or policies of either or both of the two countries with respect to the receiving of foreign investment, and, as necessary, making appropriate recom- 
mendations to the Governments of both Contracting Parties. The Joint Committee shall meet alternately in Beijing and Tokyo at the request of either Contracting Party."

The consultative mechanism would allow the Contracting Parties periodically or, for that matter, at any time, to exchange views with the possibility of revising unsatisfactory provisions or relevant municipal laws and regulations, in order to achieve the smooth implementation of the BIT.

\subsection{The impact of China's WTO accession on the implementation of BITs}

China's entry into the World Trade Organisation (WTO), will most certainly facilitate the implementation of the Chinese BITs. The WTO's mechanisms for the implementation of its rules may well strengthen the rules and disciplines embodied in the BITs. The General Agreement on Tariffs and Trade (GATT), the predecessor of the WTO and one that was basically focused on a multilateral trading system, started to pay attention to investment rules because of the growing process of world economic integration and the increasing interdependence between trade and investment. Thus the Agreement on Trade-related Investment Measures (TRIMs) and the General Agreement on Trade in Services (GATS) have now become major sources of the investment rules in the WTO framework ${ }^{86}$

A comparison between the WTO investment-related agreements and the Chinese BITs will reveal that virtually identical rules are to be found in both. As a substantial move in its bid for earlier WTO accession, China agreed to implement the TRIMs Agreement upon accession. Thus, China agrees to eliminate and cease the enforcement of trade and foreign exchange balancing requirements and local content requirements, to refuse to enforce contracts containing such requirements, and to impose or enforce laws or other provisions relating to the transfer of technology or other know-how only if these are in accordance with the WTO agreements on the protection of intellectual property rights and trade-related investment measures. The implementation of China's WTO commitments will be instrumental in the realisation of the main purpose of the Chinese BITs, i.e. facilitating investment.

As a multilateral institution, the WTO is uniquely positioned to implement investment rules and disciplines. Its dispute settlement mechanism is a major instrument to this end. ${ }^{87}$ Because of the frequent coincidence of the invest-

\footnotetext{
${ }^{86}$ For a review of the investment rules in the WTO agreements, see THOMAS L.BREWER, et al, "Investment issues at the WTO: the architecture of rules and the settlement of disputes", 1 Journal of International Economic Law (1998) 457-470.

${ }^{87}$ For the role of the WTO dispute settlement mechanism, see JOHN H.JACKSON, "Designing and implementing effective dispute settlement procedures: WTO dispute settlement, appraisal and prospects", in: ANNE O.KRUEGER (Ed.), The WTO as an International Organization (1998) 161-180.
} 
ment rules contained in the BITs and those contained in the WTO investmentrelated agreements, it should be possible, in the event of breach of the relevant rules, for the aggrieved party to have resort to the WTO dispute settlement mechanism.

\subsection{Municipal legal environment and the implementation of BITs}

The interaction between the Chinese BITs and the municipal legal environment is an important factor in the implementation of these BITs, which, to some extent, depends on the municipal legal environment. Therefore, it is desirable to approach the issue of the implementation of the Chinese BITs from the perspective of the municipal legal environment.

The flexibility of the language of bilateral treaties is well known. Whatever the balance of the bargaining powers between the two parties may be, neither is in a position to impose all the terms and conditions as it wishes without any concessions. Vague wording is thus often used to allow either to opt for its own interpretation. "Fair and equitable treatment", for instance, lacks the clarity of a definition and allows for different interpretations. Some terms and phrases need clarification through reference to municipal law, ${ }^{88}$ such as "admission of investment subject to the respective national law". Given the differences between the respective legal systems of China and of its partners, it is sometimes extremely difficult to agree on an identical or even similar interpretation. This renders the provisions less effective.

Since the municipal laws of the contracting parties of a BIT play a part in its implementation, it is useful to have a look at how Chinese law, particularly China's foreign investment law including its developments and trends, may have a bearing on the implementation of the Chinese BITs. In this context it is useful to refer briefly to the system of implementation of treaties within the framework of Chinese municipal law, in the event of conflict between the provisions of a treaty and the relevant municipal law. The Chinese government had long been uncomfortable with the rule of pacta sunt servanda. It is sometimes rescinded in treaties in accordance with its subsequently promulgated laws. However, the change in attitude of China towards international law can also be perceived in this regard. The General Principles of Civil Law now explicitly state:

\footnotetext{
${ }^{88}$ As an American commentator, C.ENGHOLM, noticed: "The Chinese, however, perceive negotiating as part of a process rather than as a goal-oriented activity; they view the signing of an agreement as the starting point rather than an armistice." The Chinese BITs, like any agreements, can not exhaust all the provisions, thus making room for municipal law to play a part in defining investment issues. Art.10 of the Sino-New Zealand BIT explicitly provides: "In order to avoid misunderstanding, the Contracting Parties hereby declare that all investments shall be subject to the appropriate law of the Contracting Party where the investments are located."
} 
"If any international treaty concluded or acceded to by the People's Republic of China contain provisions different from those in the civil laws of the People's Republic of China, the provisions of the international treaty shall apply, unless the provisions are ones with regard to which the People's Republic of China has made a reservation." 89

In view of the fundamental status of the General Principles of Civil Law the inclusion of this provision demonstrates China's strong commitment to honouring international obligations. It may thus be argued that the municipal law, even if incompatible with the BITs, poses no obstacle to their implementation.

It could be asked how municipal law could play a supplementary role in the absence of a provision or a clear definition in the BITs. It is, unfortunately, currently not possible to elaborate on the still evolving Chinese law on foreign investment and, consequently, the following brief review of the Chinese foreign investment regime, as quoted from a study of that regime by the present author, should suffice:

"It is not difficult to perceive the architectural shortcomings of China's FDI regime: lack of definitional clarity, failing to generate adequate transparency, not inherently liberalising. It is basically an incentive-based one, made up of complicated fiscal incentives and other incentives that are designed for different areas and different purposes.

However, it is too much to expect China to perfect its FDI regime by the standard of developed countries. Important is the emerging trend in the evolution of its FDI regime. The trend is characterised by a number of far-reaching changes in rule-making with respect to foreign investment. Among such changes are:

- the gradual removal of incentives;

- move towards national treatment - an effort to level the playing field for domestic enterprises and foreign investment enterprises;

- more transparency;

- translates into liberalisation of China's FDI regime.

However, these trends may, from time to time, be counterbalanced by China's intentions to keep FDI in compliance with its economic development objectives, which are subject to change.

It is important to bear in mind that the adjustment of FDI regime is not only for the sake of FDI regime per se, but because the whole economic environment upon which FDI policy rests is changing. As long as China continues to compete with other countries for FDI, given that it is unlikely for China to reverse its drive towards a market-oriented economy, China's FDI regime will continue to evolve together with

89 Art.169 of the General Principles of Civil Law. 
the shaping of the overall legal framework, characterised by the process of liberalisation. ${ }^{, 90}$

By way of final conclusion it may be argued that, notwithstanding its present difficulties and imperfections, the Chinese foreign investment regime is definitely in favour of foreign investment. There are encouraging signs that Chinese law is likely to supplement the Chinese BITs in a positive way. 